\title{
Evaluation of Infants with Retinopathy of Prematurity Treated with Intravitreal Bevacizumab
}

\section{Intravitreal Bevacizumab Uygulanan Prematüre Retinopatisi Olan Bebeklerin Değerlendirilmesi}

\author{
Sarkhan ELBAYIYEV ${ }^{1}$, Ozdemir OZDEMIR², Burak CERAN ${ }^{1}$, Mustafa Senol AKIN¹, \\ Fuat Emre CANPOLAT ${ }^{1}$, Suna OGUZ1
}

${ }^{1}$ University of Health Sciences, Ankara City Hospital, Department of Neonatology, Ankara, Turkey

${ }^{2}$ University of Health Sciences, Ankara City Hospital, Department of Ophtalmology, Ankara, Turkey

\begin{abstract}
Objective: To evaluate the systemic and local effects and side effects of intravitreal bevacizumab injection in preterm infants with aggressive posterior retinopathy of prematurity.

Material and Methods: A total of 16 patients were included in this single-center observational cohort study between June 2020 and March 2021. The clinical, laboratory, and radiological findings before and after intravitreal injection of 0.3 mg bevacizumab were recorded for a total of 32 eyes.

Results: The patients' mean gestational age at birth was $25 \pm 0.38$ weeks and their mean birth weight was $695 \pm 119.2$ g. None of the patients developed complications such as local vitreous hemorrhage or endophthalmitis secondary to intravitreal injection administered at a postmenstrual age of 34 weeks, and none required repeated injections. There was no increase in the rate of intraventricular hemorrhage after injection. There was no statistically significant difference in the patients' laboratory parameters, blood pressure values, or systemic findings before and after treatment.

Conclusion: Although no systemic or local side effects were observed in patients treated with intravitreal bevacizumab injection in this study, patients should be monitored closely for systemic hypertension, intraventricular hemorrhage, and hypotension. More detailed studies are needed to evaluate later neurodevelopmental outcomes compared to other treatment options.
\end{abstract}

Key Words: Bevacizumab, Hypertension, Hypotension, Intracranial Hemorrhage, Retinopathy of Prematurity

Öz

Amaç: Agresif posterior prematüre retinopatisi olan prematüre bebeklerde intravitreal bevacizumab enjeksiyonunun sistemik, lokal etkilerini ve yan etkilerini değerlendirmek.

Gereç ve Yöntemler: Haziran 2020 ile Mart 2021 arasında tek merkezli gözlemsel kohort çalışmasına toplam 16 hasta dahil edildi. Toplam 32 göz için intravitreal $0.3 \mathrm{mg}$ bevacizumab enjeksiyonu öncesi ve sonrası klinik, laboratuvar ve radyolojik bulgular kaydedildi.

Bulgular: Hastaların doğumdaki ortalama gestasyonel yaşı $25 \pm 0.38$ hafta ve ortalama doğum ağırlı̆ı $695 \pm 119.2$ gr'dı. Hiçbir hastada postmenstrüel 34 haftallkken intravitreal enjeksiyona sekonder lokal vitreus kanaması veya endoftalmit gibi komplikasyonlar gelişmedi, hiçbirinde tekrarlanan enjeksiyon gerekmedi. Enjeksiyondan sonra intraventriküler

\section{(1)}

0000-0002-2113-5591: ELBAYIYEV S 0000-0002-4833-8567: OZDEMIR O 0000-0001-5914-5325: CERAN B 0000-0003-0055-8277: AKIN MS 0000-0001-9307-3003: CANPOLAT FE 0000-0002-1870-0983: OGUZ S

\begin{abstract}
Conflict of Interest / Çıkar Çatışması: On behalf of all authors, the corresponding author states that there is no conflict of interest.
Ethics Committee Approval / Etik Kurul Onayı: The observational cohort study was approved by the Ankara City Hospital, Clinical Research No. 1 ethics committee (11.06.2020, E1-748).

Contribution of the Authors / Yazarların katkısI: ELBAYIYEV S: Constructing the hypothesis or idea of research and/or article, Planning methodology to reach the Conclusions, Taking responsibility in necessary literature review for the study, Taking responsibility in the writing of the whole or important parts of the study. OZDEMIR O: Taking responsibility in patient follow-up, collection of relevant biological materials, data management and reporting, execution of the experiments. CERAN B: Taking responsibility in necessary literature review for the study. AKIN MS: Taking responsibility in patient follow-up, collection of relevan biological materials, data management and reporting, execution of the experiments. CANPOLAT FE: Organizing, supervising the course of progress and taking the responsibility of the research/study, Taking responsibility in logical interpretation and conclusion of the results. OGUZ S: Organizing, supervising the course of progress and taking the responsibility of the research/study, Taking responsibility in logical interpretation and conclusion of the results. Reviewing the article before submission scientifically besides spelling and grammar.

How to cite / Atıf yazım şekli : Elbayıyev S, Ozdemir O, Ceran B, Kurt MS, Canpolat FE and Oguz S. Evaluation of Infants with Retinopathy of Prematurity Treated with Intravitreal Bevacizumab. Turkish J Pediatr Dis 202X;
\end{abstract}

Correspondence Address / Yazıșma Adresi:

Sarkhan ELBAYIYEV

University of Health Sciences, Ankara City Hospital,

Department of Neonatology, Ankara, Turkey

E-posta: serxanelbayiyev@gmail.com
Received / Geliş tarihi : 02.10.2021 Accepted / Kabul tarihi : 19.11.2021

Online published 24.02.2022

Elektronik yayın tarihi

DOI: 10.12956/tchd.1003824 
kanama oranında artış olmadı. Tedavi öncesi ve sonrası hastaların laboratuvar parametreleri, kan basıncı değerleri veya sistemik bulguları arasında istatistiksel olarak anlamlı bir fark yoktu.

Sonuç: Bu çalışmada intravitreal bevacizumab enjeksiyonu ile tedavi edilen hastalarda sistemik veya lokal yan etki görülmemekle birlikte hastalar sistemik hipertansiyon, intraventriküler kanama ve hipotansiyon açısından yakından izlenmelidir. Diğer tedavi seçeneklerine kıyasla daha sonraki nörogelişimsel sonuçları değerlendirmek için daha ayrıntılı çalışmalara intiyaç vardır.

Anahtar Sözcükler: Bevacizumab, Hipertansiyon, Hipotansiyon, İntrakraniyal Kanama, Prematüre Retinopatisi

\section{INTRODUCTION}

Retinopathy of prematurity (ROP) occurs secondary to abnormal vasoproliferation in the retina of preterm infants and is among the leading causes of blindness. The Turkish ROP Neonatal Study Group reported the incidence of ROP in Turkey as 8.1\% in infants with low birth weight (LBW) and $19.4 \%$ in infants with extremely low birth weight (ELBW) (1). In the TR-ROP study, birth weight, gestational age, duration of oxygen therapy, and relative weight gain at postnatal 28 days were found to be independent risk factors for ROP (2). Although the incidence of ROP is gradually decreasing due to well-planned screening programs, clinical studies investigating new risk groups and different treatment modalities are needed.

Aggressive posterior ROP (APROP) is a form characterized by plus disease in zone I and posterior zone II disproportionate to peripheral disease findings, and it can lead to retinal detachment without early diagnosis and treatment (3). Laser photocoagulation and intravitreal anti-vascular endothelial growth factor (VEGF) agents (bevacizumab, ranibizumab) are commonly used in its treatment. There are publications suggesting that anti-VEGF agents provide better visual outcomes than laser photocoagulation in the treatment of APROP involving zone I (4,5). However, anti-VEGF agents have also been reported to cause adverse effects such as hypotension, hypertension, and intracranial hemorrhage $(\mathrm{ICH})$ $(6,7)$. In this single-center study, the clinical, radiological, and laboratory results of patients with APROP who required intravitreal bevacizumab injection (IVI) were examined for possible side effects after the procedure.

\section{MATERIAL and METHODS}

The ROP Diagnosis, Treatment, and Education Center, which operated within the Dr. Zekai Tahir Burak Women's Health Training and Research Hospital from 2004 until becoming affiliated with Ankara City Hospital, is one of the first centers in Turkey to implement a monitoring program for ROP. It continues to serve as the highest volume diagnosis and treatment center. The center provides ROP screening and treatment for infants born in and/or followed up in the neonatal intensive care unit (NICU) of the same hospital, as well as infants at-risk infants from the province and by the national emergency call center.
This study included patients diagnosed as having APROP and treated with intravitreal bevacizumab between June 2020 and March 2021. The observational cohort study was approved by the local ethics committee in the institution where the clinical study was conducted (date 11.06.2020, E1-20-748).

\section{Retinal examination:}

Ophthalmologists qualified and competent in the area of ROP performed retinal examinations using 20- and 28-diopter lenses after placing a lid speculum. The infants were placed in supine position for the examinations, which were performed at bedside in the NICU under appropriate monitoring. To visualize the retina and vitreous, mydriasis was induced with 2.5\% phenylephrine and $0.5 \%$ tropicamide 2 to 3 times at 5 -minute intervals, starting 1 hour before the examination. Patients with ideal pupil dilation were examined 45 to 60 minutes after the last instillation. ROP was classified according to the ICROP (International Classification of Retinopathy of Prematurity) $(1,2)$.

\section{Intravitreal Injections:}

The advantages, disadvantages, and expected benefits of laser photocoagulation and intravitreal bevacizumab injection in the treatment of ROP were explained in detail to the parents and their informed consent was obtained. Intravitreal injections were administered $1.5 \mathrm{~mm}$ from the limbus under appropriate sedation and sterile conditions. Bevacizumab $0.3 \mathrm{mg} / 0.0125 \mathrm{ml}$ was used as the anti-VEGF agent. All injections were performed by the same specialist ophthalmologist (O.O.). Moxifloxacin eye drops were used 4 times a day for 5 days as post-procedure endophthalmitis prophylaxis.

Data regarding the preterm infants' demographic characteristics (gestational age, birth weight, sex, mode of delivery, need for resuscitation in the delivery room) and antenatal/postnatal risk factors (clinical chorioamnionitis, prelabor rupture of membranes at term [PROM] or preterm [PPROM], preeclampsia, antenatal corticosteroid therapy) were obtained from medical records.

\section{Additionally, the following were also recorded:}

- Respiratory distress syndrome (RDS) requiring surfactant (8),

- Hemodynamically significant patent ductus arteriosus (hsPDA) requiring treatment (echocardiographically documented with continuous murmur, hyperdynamic 
precordium, left-to-right shunt, pulsatile pulse and wide pulse pressure, increased oxygen requirement, cardiomegaly, and congestive heart failure) (9),

- Early neonatal sepsis (within first 72 hours in very low birth weight infants) and late neonatal sepsis (after 3 days) (10),

- Time to oral intake, necrotizing enterocolitis (NEC) higher than stage llb according to Bell staging (11),

- Oxygen requirement at postnatal 7, 14, 21, and 28 days and duration of invasive and non-invasive mechanical ventilation (MV),

- Intraventricular hemorrhage (IVH; ventricular enlargement and periventricular infarction stage 3 according to Volpe staging) (12), concomitant diseases, and late morbidities.

Hematological and biochemical parameters, IVH presence and stage, systolic, diastolic, and mean arterial blood pressure (BP) values measured using an appropriate sleeve, and ocular findings 48 hours before and 96 hours after intravitreal bevacizumab injection were obtained from patient records and the hospital database.

\section{Statistical analysis:}

Statistical analyses were performed using SPSS version 22.0 (IBM Corp, Armonk, NY). p values < 0.05 were accepted as statistically significant. Normal distribution of measured values were analyzed graphically and with Shapiro-Wilk test. Results were presented as mean and standard deviation or median, minimum, and maximum values. Paired-samples $t$ test was used to compare patients' pre- and post-treatment values.

\section{RESULTS}

The patients' mean gestational age at birth was $25 \pm 0.38$ weeks and their mean birth weight was $695 \pm 119.2 \mathrm{~g}$. Of the 16 infants in the study, 11 (68.8\%) were female, 13 (81\%) were born by cesarean section, 14 (87.5\%) underwent advanced resuscitation in the delivery room, and all received endotracheal surfactant therapy. Ten (62.5\%) of the preterm infants had received a complete course of antenatal steroid, while 4 (25\%) received no antenatal corticosteroid therapy. Other risk factors and diseases are summarized in Table I.

Intravitreal bevacizumab injection was administered to a total of 32 eyes at a mean postmenstrual age of $34 \pm 0$ weeks. Stage I-II ROP and plus disease were detected in 12 infants (75\%) and APROP in zone I was detected in 10 infants (62.5\%). None of the patients required repeated injections and none developed complications associated with the procedure. There was no increase in the rate of IVH after injection. There were no statistically significant differences in the patients' laboratory parameters, blood pressure values, or systemic findings before and after treatment (Table II).

\section{Table I: Summary of the antenatal and clinical characteristics of preterm infants with ROP $(n=16)$. Data presented as mean \pm standard deviation or number and percentage.}

\begin{tabular}{|c|c|}
\hline Birth weight, $g$ & $695 \pm 119.2$ \\
\hline Gestational age, weeks & $25 \pm 0.38$ \\
\hline $\operatorname{Sex}(F), n(\%)$ & $11(68.8)$ \\
\hline Mode of birth (C/S), n (\%) & $13(81.0)$ \\
\hline $\begin{array}{l}\text { Complete course of antenatal } \\
\text { corticosteroid }\end{array}$ & $10(62.5)$ \\
\hline No antenatal corticosteroid & $4(25.0)$ \\
\hline Preeclampsia & $1(6.3)$ \\
\hline Chorioamnionitis & $2(12.5)$ \\
\hline PPROM & $4(25.0)$ \\
\hline Resuscitation in the delivery room & $14(87.5)$ \\
\hline Early neonatal sepsis & $8(50.0)$ \\
\hline Late neonatal sepsis & $15(93.8)$ \\
\hline hsPDA & $11(68.8)$ \\
\hline Day 7 Invasive ventilation & 5 (33.3) \\
\hline Day 14 Invasive ventilation & 9 (56.3) \\
\hline Day 21 Invasive ventilation & $8(50.0)$ \\
\hline Day 28 Invasive ventilation & $4(25.0)$ \\
\hline MV duration, (days) & $37.4 \pm 22.3$ \\
\hline NIV duration, (days) & $24.1 \pm 13.0$ \\
\hline BPD mild/moderate & $6(37.5)$ \\
\hline BPD severe & $10(62.5)$ \\
\hline Oral intake start time, (days) & $3 \pm 0.3(2-4)$ \\
\hline Rate of weight gain, (g/day) & $13.3 \pm 4.4$ \\
\hline Necrotizing enterocolitis & $7(43.8)$ \\
\hline Intraventricular hemorrhage & 5 (31.3) \\
\hline Stage I-II ROP/APROP & $12(75.0)$ \\
\hline Stage III APROP & $4(25.0)$ \\
\hline Zone I APROP & $10(62.5)$ \\
\hline Zone II APROP & $6(37.5)$ \\
\hline Pre-treatment systolic BP, (mmHg) & $88 \pm 8.8(81-93)$ \\
\hline Post-treatment systolic BP, (mmHg) & $91 \pm 7.7(83.2-95.7)$ \\
\hline Pre-treatment diastolic BP, (mmHg) & $52.5 \pm 7.5(47.7-60)$ \\
\hline Post-treatment diastolic BP, $(\mathrm{mmHg})$ & $54.5 \pm 5.6(51-57)$ \\
\hline Pre-treatment mean BP, $(\mathrm{mmHg})$ & $63.5 \pm 7.6(57-70.7)$ \\
\hline Post-treatment mean BP, (mmHg) & $65.5 \pm 7.2(60-69.7)$ \\
\hline
\end{tabular}

F: Female, C/S: Cesarean section, PPROM: Preterm prelabor rupture of membranes, hsPDA: Hemodynamically significant patent ductus arteriosus, MV: Mechanical ventilation, NIV: Noninvasive mechanical ventilation, BPD: Bronchopulmonary dysplasia, ROP: Retinopathy of prematurity, APROP: Aggressive posterior ROP, BP: Blood pressure 
Table II: Comparison of blood and blood pressure parameters before and after intravitreal bevacizumab therapy.

\begin{tabular}{l|c|c|c|}
\hline & Pre-treatment & Post-treatment & p \\
\hline CRP, (mg/dL) & $3.6(1.15-25)$ & $3.2(1.0-10.9)$ & 0.160 \\
\hline WBC, (x109/L) & $7655.0 \pm 675.5$ & $7720.6 \pm 664.9$ & 0.870 \\
\hline $\mathrm{Hb},(\mathrm{g} / \mathrm{dL})$ & $9.7 \pm 0.5$ & $9.8 \pm 0.5$ & 0.490 \\
\hline $\mathrm{PLT}\left(\times 10^{9} / \mathrm{L}\right)$ & $340562 \pm 53740$ & $349812 \pm 53133$ & 0.710 \\
\hline Systolic BP (highest), $\mathrm{mmHg}$ & 93 & 95 & 0.460 \\
\hline Diastolic BP (highest), $\mathrm{mmHg}$ & 60 & 57 & 0.880 \\
\hline Mean BP (highest), $\mathrm{mmHg}$ & 70 & 69 & 0.950 \\
\hline Systolic BP (lowest), $\mathrm{mmHg}$ & 81 & 83 & 0.840 \\
\hline Diastolic BP (lowest), $\mathrm{mmHg}$ & 47 & 51 & 0.130 \\
\hline Mean BP (lowest), $\mathrm{mmHg}$ & 57 & 60 & 0.250 \\
\hline
\end{tabular}

CRP: C-reactive protein, WBC: White blood cells, Hb: Hemoglobin, PLT: Platelets, BP: Blood pressure

\section{DISCUSSION}

The results of this study indicate that intravitreal bevacizumab therapy can be safely used in very low birth weight preterm infants, has no effect on vital signs and blood parameters, and is not associated with important morbidities of prematurity. As ethical considerations preclude randomized controlled or placebo-controlled studies in critical, sight-threatening diseases that require urgent treatment such as APROP, sharing drug side effects and observed complications through retrospective cohort studies and case reports is more valuable scientifically.

In 2013, the American Academy of Pediatrics and American Academy of Ophthalmology recommended ROP screening for all infants with birth weight $\leq 1500 \mathrm{~g}$ and/or gestational age $\leq$ 30 weeks and those infants born after 30 weeks of gestation with birth weight of 1500-2000 $\mathrm{g}$ and clinical problems requiring cardiopulmonary support (13). In Turkey, it is generally recommended to screen all infants born at or before 32 weeks of gestation. The first eye examination is performed at 3031 weeks of postmenstrual age for all infants born before 27 weeks of gestation and at postnatal 4 weeks for infants born after 27 weeks of gestation (2).

The pathogenesis of ROP is explained by the development of abnormal neovascularization due to elevated VEGF and insulinlike growth factor-1 (IGF-1) levels, and the most important risk factors are prematurity and low birth weight (14). Elevated inflammatory markers secondary to complement activation have been shown to be useful in the prediction of ROP and early intervention (15). In a meta-analysis of ROP risk factors, prenatal steroid use, gestational age, MV duration, and RDS were associated with ROP development, while gestational age, bronchopulmonary dysplasia (BPD), erythrocyte suspension transfusion count, $\mathrm{ICH}$, and periventricular leukomalacia were associated with ROP progression (16). In the present study, $62.5 \%$ of the infants received a complete course and $12.5 \%$ received a half course of prenatal corticosteroid, the mean gestational age was 25 weeks, the mean duration of MV was
37 days, 93.8\% received surfactant, $62.5 \%$ had severe BPD, and $31.3 \%$ had $\mathrm{ICH}$. Lee et al. (17) and Anaya-Alaminos et al. (18) determined that the preterm infants of mothers with PROM had a lower risk of severe ROP, whereas preterm infants with bacteremia and postnatal hyperoxemia were at higher risk of severe ROP. The prevalence of PPROM was $25 \%$ in this study. In a meta-analysis investigating the association between sepsis and ROP, sepsis was found to be directly associated with all stages of ROP (19). Late neonatal sepsis was observed in nearly all of the patients in the present study. There are also studies demonstrating a direct association with chorioamnionitis and funisitis (20).

As ROP is a preventable disease, preterm infants weighing less than $1500 \mathrm{~g}$ should receive oxygen therapy with saturation monitoring in accordance with established guidelines (21). For the conditions in Turkey, it is recommended to monitor infants with gestational age $\leq 34$ weeks and birth weight $<1700 \mathrm{~g}$ according to the routine screening program (2). A model incorporating postnatal growth into ROP screening (G-ROP) has recently been developed for preterm infants who do not meet conventional birth weight and gestational age criteria, and gestational age $<28$ weeks, birth weight $<1051 \mathrm{~g}$, weight gain $<120$ g during postnatal days $10-19$, weight gain $<180 \mathrm{~g}$ during days 20-29, weight gain $<170 \mathrm{~g}$ during days $30-39$, and hydrocephalus were reported as poor prognostic factors (22). Treatment tment modalities commonly used for ROP include cryotherapy, laser photocoagulation, IVI, and retinal surgery (23).

APROP is the most aggressive form of ROP and its treatment is more challenging compared to classical ROP (3). A study investigating APROP risk factors found that maternal chorioamnionitis and intrauterine growth restriction (IUGR) were directly associated with APROP (24). Only two of the patients in this study had chorioamnionitis, and none had IUGR. In a routine ROP screening program, APROP was detected in a series of 3 infants born at gestational ages of 27 weeks, 305/7 weeks, and 31 weeks, and the authors emphasized the potentially aggressive course of this disease 
and the importance of close monitoring and follow-up of risk groups (25).

Anti-VEGF agents are frequently used together with laser photocoagulation in the treatment of APROP (26). In some studies, anti-VEGF injection is recommended as rescue therapy in cases of laser photocoagulation failure (27). However, in a small number of series, it was shown that laser photocoagulation can be used if the disease progresses after IVI (28). Although uncommon, some complications such as cataract, vitreous hemorrhage, corneal abrasion/opacity, endophthalmitis, hyphema, and thromboembolic events may develop after bevacizumab injection (29). As in our study, there are publications reporting no complications after IVI $(30,31)$. A recent meta-analysis by Popovic et al. (32) comparing IVI and laser photocoagulation showed that the need for repeat treatment was less common after laser photocoagulation, astigmatism and the need for surgery were lower after IVI, and there was no significant difference between IVI and laser photocoagulation in terms of vision, safety, and disease regression times. In a study showing that IVI therapy was at least as effective as laser photocoagulation and that the risk of complications and retreatment was lower, the degree of myopia was found to be higher in APROP patients compared to type 1 ROP patients (33-35).

Intravitreal bevacizumab injection is also frequently used in our clinic. As in this study, Nicoara et al. (36) administered intravitreal bevacizumab to patients with APROP and stage 3 $\mathrm{ROP}$ and observed significant regression of ROP findings, with no complications or retinal detachment. There are publications demonstrating a greater need for laser photocoagulation and retinal surgery in the APROP group after bevacizumab treatment for APROP and type 1 ROP (37). APROP has a high risk of recurrence and was found to be correlated with intravitreal hemorrhage, low birth weight, postmenstrual age, and low neutrophil count in one study (38).

Opinions are divided regarding bevacizumab dosing for the treatment of APROP. In a study comparing doses of $0.5 \mathrm{mg}$ and $0.625 \mathrm{mg}$, no difference in complications was observed between the groups (39). The patients in the present study were administered $0.3 \mathrm{mg}$ intravitreal bevacizumab with no complications. Systemic hypotension, hypertension, and $\mathrm{ICH}$ after bevacizumab treatment have been reported in small cases series $(6,7)$. The patients in this study had no increase in $\mathrm{ICH}$ and no change in systemic blood pressure values after injection.

Limitations of this study is small number of cases due to the inclusion of high-risk infants with low gestational age.

\section{CONCLUSION}

Although intravitreal bevacizumab therapy is widely used in the treatment of APROP, side effects such as systemic hypertension, hypotension, and $\mathrm{ICH}$ risk have been reported. However, no systemic or local side effects were observed in the injected eyes in this study. Additionally, none of the treated eyes required a second injection or laser treatment during follow-up. Nevertheless, ROP patients who receive intravitreal injections should be monitored closely for possible short-term drug side effects. More extensive studies are needed to determine the dose with highest efficacy and lowest side effects, and later neurodevelopmental outcomes should be investigated in comparison with other treatment options.

\section{REFERENCES}

1. Bas AY, Koc E, Dilmen U. Incidence and severity of retinopathy of prematurity in Turkey. Br J Ophthalmol 2015;99:1311-4.

2. Bas AY, Demirel N, Koc E, Ulubas Isik D, Hirfanoglu I M, Tunc T. Incidence, risk factors and severity of retinopathy of prematurity in Turkey (TR-ROP study): a prospective, multicentre study in 69 neonatal intensive care units. Br J Ophthalmol 2018;102:1711-6.

3. International Committee for the Classification of Retinopathy of Prematurity. The International Classification of Retinopathy of Prematurity revisited. Arch Ophthalmol 2005;123:991-9.

4. Gunay M, Sukgen EA, Celik G, Kocluk Y. Comparison of Bevacizumab, Ranibizumab, and Laser Photocoagulation in the Treatment of Retinopathy of Prematurity in Turkey. Curr Eye Res 2017;42:462-9.

5. Blair M, Gonzalez JMG, Snyder L, Schechet S, Greenwald M, Shapiro $\mathrm{M}$, et al. Bevacizumab or laser for aggressive posterior retinopathy of prematurity. Taiwan J Ophthalmol 2018;8:243-8.

6. Wu LH, Yang YH, Lin CH, Lin YJ, Cheng CL. Hypotension Associated With Intravitreal Bevacizumab Therapy for Retinopathy of Prematurity. Pediatrics 2016;137:e20152005.

7. Twitty G, Weiss M, Albayram MS, O'Mara K, Mowitz ME. Hypertension and Neuroimaging Changes After Bevacizumab for Retinopathy of Prematurity. Pediatrics 2020;145: e20191814.

8. Sweet DG, Carnielli V, Greisen G, Hallman M, Ozek E, Te Pas $A$, et al. European Consensus Guidelines on the Management of Respiratory Distress Syndrome - 2019 Update. Neonatology 2019;115:432-50.

9. Mitra S, Florez ID, Tamayo ME, Aune D, Mbuagbaw L, Veroniki $A A$, et al. Effectiveness and safety of treatments used for the management of patent ductus arteriosus (PDA) in preterm infants: a protocol for a systematic review and network meta-analysis. BMJ open 2016;6:e011271.

10. Camacho-Gonzalez A, Spearman PW, Stoll BJ. Neonatal infectious diseases: evaluation of neonatal sepsis. Pediatr Clin North Am 2013;60:367-89.

11. Bell MJ, Ternberg JL, Feigin RD, Keating JP, Marshall R, Barton L, et al. Neonatal necrotizing enterocolitis. Therapeutic decisions based upon clinical staging. Ann surg 1978;187:1-7.

12. Parodi A, Govaert P, Horsch S, Bravo MC, Ramenghi LA. Cranial ultrasound findings in preterm germinal matrix haemorrhage, sequelae and outcome. Pediatr Res 2020;87:13-24.

13. Fierson WM. Screening examination of premature infants for retinopathy of prematurity. Pediatrics 2013;131:189-95.

14. Quimson SK. Retinopathy of Prematurity: Pathogenesis and Current Treatment Options. Neonatal Netw 2015;34:284-7. 
15. Rathi S, Jalali S, Patnaik S, Shahulhameed S, Musada GR, Balakrishnan D, et al. Abnormal Complement Activation and Inflammation in the Pathogenesis of Retinopathy of Prematurity. Front Immunol 2017;8:1868.

16. Chang JW. Risk factor analysis for the development and progression of retinopathy of prematurity. PloS one 2019;14:e0219934.

17. Lee JW, McElrath T, Chen M, Wallace DK, Allred EN, Leviton A, et al. Pregnancy disorders appear to modify the risk for retinopathy of prematurity associated with neonatal hyperoxemia and bacteremia. J Matern Fetal Neonatal Med 2013;26:811-8.

18. Anaya-Alaminos R, García-Serrano JL, Cantero-Hinojosa J. Prenatal and postnatal factors increase risk of severe ROP. J Matern Fetal Neonatal Med 2014;27:635-6.

19. Wang X, Tang K, Chen L, Cheng S, Xu H. Association between sepsis and retinopathy of prematurity: a systematic review and meta-analysis. BMJ open 2019;9:e025440.

20. Villamor-Martinez E, Cavallaro G, Raffaeli G, Mohammed Rahim OMM, Gulden S, Ghazi AMT, et al. Chorioamnionitis as a risk factor for retinopathy of prematurity: An updated systematic review and meta-analysis. PloS one 2018;13:e0205838.

21. Visser L, Singh R, Young M, Lewis H, McKerrow N. Guideline for the prevention, screening and treatment of retinopathy of prematurity (ROP). S Afr Med J 2012;103:116-25.

22. Lin L, Binenbaum G. Postnatal weight gain and retinopathy of prematurity. Semin Perinatol 2019;43:352-9.

23. Hartnett ME. Advances in understanding and management of retinopathy of prematurity. Surv Ophthalmol 2017;62:257-76.

24. Ahn YJ, Hong KE, Yum HR, Lee JH, Kim KS, Youn YA, et al. Characteristic clinical features associated with aggressive posterior retinopathy of prematurity. Eye (Lond) 2017;31:924-30.

25. Gupta MP, Yonekawa Y, Campbell JP, Rusu I, Zahid S, Patel SN, et al. Early Diagnosis and Management of Aggressive Posterior Vitreoretinopathy Presenting in Premature Neonates. Ophthalmic Surg Lasers Imaging Retina 2019;50:201-7.

26. Sankar MJ, Sankar J, Chandra P. Anti-vascular endothelial growth factor (VEGF) drugs for treatment of retinopathy of prematurity. Cochrane Database Syst Rev 2018;1:CD009734.

27. Kara C, Hekimoglu E, Petricli IS, Akil H. Intravitreal bevacizumab as rescue therapy following treatment failure with laser photocoagulation in retinopathy of prematurity. J Curr Ophthalmol 2018;30:80-4.

28. Tandon M, Vishal MY, Kohli P, Rajan RP, Ramasamy K. Supplemental Laser for Eyes Treated with Bevacizumab Monotherapy in Severe Retinopathy of Prematurity. Ophthalmol Retina 2018;2:623-8.
29. Bazvand F, Riazi-Esfahani $H$, Mirshahi A, Khodabande A, Khojastheh $\mathrm{H}$, Farahani $\mathrm{AD}$, et al. Ocular complications following intravitreal bevacizumab injection for retinopathy of prematurity and assessment of risk factors. Int J Retina Vitreous 2021;7:5.

30. Shoeibi N, Hosseini SM, Banaee T, Ansari-Astaneh MR, Abrishami $\mathrm{M}$, Ahmadieh $\mathrm{H}$. Vitreous changes after intravitreal bevacizumab monotherapy for retinopathy of prematurity: a case series. Int $J$ Retina Vitreous 2018;4:10.

31. Kang HG, Choi EY, Byeon SH, Kim SS, Koh HJ, Lee SC, et al. Anti-vascular Endothelial Growth Factor Treatment of Retinopathy of Prematurity: Efficacy, Safety, and Anatomical Outcomes. Korean J Ophthalmol 2018;32:451-8.

32. Popovic MM, Nichani P, Muni RH, Mireskandari K, Tehrani NN, Kertes PJ. Intravitreal antivascular endothelial growth factor injection versus laser photocoagulation for retinopathy of prematurity: A meta-analysis of 3,701 eyes. Surv Ophthalmol 2021;66:572-84.

33. Wang SD, Zhang GM, Shenzhen Screening for Retinopathy of Prematurity Cooperative G. Laser therapy versus intravitreal injection of anti-VEGF agents in monotherapy of ROP: a Metaanalysis. Int J Ophthalmol 2020;13:806-15.

34. Frosini S, Franco F, Vicini G, Nicolosi C, Varriale G, Dani $C$, et al. Efficacy and safety of intravitreal bevacizumab for the treatment of retinopathy of prematurity: a single-center retrospective review. J Matern Fetal Neonatal Med 2020:1-6. doi: 10.1080/14767058.2020.1818214.

35. Gunay M, Celik G, Gunay BO, Aktas A, Karatekin G, Ovali F. Evaluation of 2-year outcomes following intravitreal bevacizumab (IVB) for aggressive posterior retinopathy of prematurity. Arq Bras Oftalmol 2015;78:300-4.

36. Nicoara SD, Nascutzy C, Cristian C, Irimescu I, Stefanut AC, Zaharie G, et al. Outcomes and Prognostic Factors of Intravitreal Bevacizumab Monotherapy in Zone I Stage 3+ and Aggressive Posterior Retinopathy of Prematurity. J Ophthalmol 2015;2015:102582.

37. Eftekhari Milani A, Hassanpoor N, Mousavi Mirkala M, Taheri A, Golizade A, Niyousha MR. Intravitreal bevacizumab injection in aggressive posterior retinopathy of prematurity compared with type I retinopathy of prematurity. Int Ophthalmol 2020;40:477-82.

38. Tong $Q$, Yin $H$, Zhao M, Li X, Yu W. Outcomes and prognostic factors for aggressive posterior retinopathy of prematurity following initial treatment with intravitreal ranibizumab. BMC Ophthalmol 2018;18:150. doi: 10.1186/s12886-018-0815-1.

39. Dikci S, Ceylan OM, Demirel S, Yilmaz T. Which dose of bevacizumab is more effective for the treatment of aggressive posterior retinopathy of prematurity: lower or higher dose? Arq Bras Oftalmol 2018;81:12-7. 